\title{
EL REALISMO FANTÁSTICO SEVILLANO COMO EXPLORACIÓN DE UNA NUEVA FIGURACIÓN
}

\author{
THE SEVILLIAN FANTASTIC REALISM AS \\ EXPLORATION OF A NEW FIGURATION
}

\author{
Fernando Martín Martín \\ Universidad de Sevilla. España \\ fmm@us.es
}

\begin{abstract}
El presente artículo analiza la práctica del Realismo Fantástico en Sevilla en la década de los setenta, como entidad singular de un modo de concebir la figuración y como reflejo de una "vuelta a la pintura" representada por un grupo destacado de representantes de esta tendencia.

Palabras clave: pintura; Sevilla; Realismo Fantástico; Realismo Mágico; figuración.
\end{abstract}

This paper analyzes the practice of Fantastic Realism in Seville in the 1970s, as a singular entity of a way of conceiving figuration and as a reflection of a "return to painting" represented by a group of prominent representatives of this trend.

Keywords: painting; Seville; Fantastic Realism; Magic Realism; figuration.

Siempre he creído que es pertinente, al utilizar un concepto, aclarar su significado y, partiendo de él, comprobar hasta qué punto su aplicación se ajusta a la realidad. A los autores que integraron la exposición Con luz propia. Pintores del Realismo Mágico sevillano ${ }^{1}$, cuya obra está realizada mayoritariamente durante la década de los setenta del siglo pasado, se les ha definido estilísticamente como componentes del "Realismo Mágico", calificación inadecuada a la idea primigenia de dicho movimiento. El término de "Realismo Mágico" fue empleado por primera vez por el crítico alemán Franz Roh en su libro publicado en 1925 Realismo Mágico. Postexpresionismo, coincidente en el tiempo con la exposición

${ }^{1}$ Dicha exposición tuvo lugar entre el 30 de noviembre de 2017 y 14 de enero de 2018 en el Museo de Alcalá de Guadaíra. 
Nueva Objetividad (Neue Sachlindikeit), celebrada en el Kunsthalle de la ciudad de Manhein y organizada por el historiador Gustav Fredereich Hastlaul. Denominación que solapó rápidamente el epíteto ofrecido en el texto de Roh².

La Nueva Objetividad (1918-1933) fue una respuesta dual. Por una parte es la reacción a los expresionismos germánicos Die Brucke (El Puente, 1905) y El Jinete Azul (Der Blaue Reiter, 1911). Por otra, y no menos importante y extensiva a otros países europeos, fue La vuelta al Orden, expresada por un retorno a una figuración más verista y formal. Se alejó de los excesos de las vanguardias surgidas anteriormente a 1914, y se declaró a favor de un naturalismo que reflejaba la situación crítica y degradada de la Alemania de posguerra ${ }^{3}$.

El empleo de la noción "Realismo Mágico", asociada a ciertas obras por parte de la crítica entre los años sesenta y setenta en España, está relacionada con dos hechos. Uno de carácter plástico, como es la alternativa a los informalismos y prácticas abstractas en la llamada "Nueva Figuración", caracterizada en una diversidad lingüística. Y otra, mucho más consistente, como es la referencia a la corriente literaria latinoamericana expresada en obras como El reino de este mundo de Alejo Carpentier en 1949, Cien años de soledad de Gabriel García Márquez en 1967 y Como agua para chocolate de Laura Esquivel en 1989, entre otras. Todas ellas ejemplifican bien la existencia de lo Mágico e Irreal en narraciones desarrolladas en el contexto de la vida cotidiana.

Atendiendo pues a las consideraciones expuestas, creemos que la etiqueta "Realismo Mágico", asignada a veces por la crítica a las obras que conformaron la mencionada muestra, no se ajusta al modelo de tal tendencia, y sí dentro del contexto de la "Nueva Figuración" surgida en los años antes señalados en España y que en Sevilla, por razones de carácter histórico, sociológico y, por supuesto, artístico, tiene una entidad propia. En este sentido sería más apropiado referirse -y siempre dentro del marco del Realismo sevillano- a "Realismo Fantástico", una suerte de realismo que es, por otra parte, constante en la historia del Arte ${ }^{4}$.

En las causas que explican esta modalidad pictórica en Sevilla deben tenerse en cuenta ciertos factores relevantes, como son la persistencia de la tradición

${ }^{2}$ Véase VV.AA.: Realismo mágico. Franz Roh y la pintura europea. 1917-1936. Valencia, 1997. Con motivo de dicha exposición se reeditó en facsímil el libro de ROH, Franz: Realismo mágico. Postexpresionismo. Madrid, 1927.

${ }^{3}$ Véase VV.AA.: Les realismes. 1919-1939. París, 1980.

${ }^{4}$ Con frecuencia, al estudiar el arte andaluz de posguerra, y más concretamente al efectuado en Sevilla por algunos pintores de la década de los setenta, se le ha calificado dentro del llamado "Realismo Mágico", calificación, como hemos apuntado ya en el texto, equívoca. Véase GUASCH, Ana: "Los realismos y el realismo sevillano", en Cuarenta años de pintura en Sevilla. 1940-1980. Sevilla, 1981, pp. 44-46; y GAMONAL TORRES, Miguel Ángel: "Los realismos", en Medio siglo de vanguardias. Sevilla, 1994, pp. 387-395. 
figurativa y la ausencia de una verdadera modernidad solo alcanzada de manera clara en los años setenta, periodo en el que se iniciará el "Realismo Fantástico". En esos años una serie de hechos acredita una efervescencia cultural en la ciudad, atestiguada por la proliferación de galerías de arte: Imagen múltiple, Centro M-11, Juana de Aizpuru - cuya apertura coincide con la del Museo de Arte Contemporáneo-, y Haurie -auténtica plataforma expositiva del "Realismo Fantástico"-. Sin olvidar tampoco los auspicios culturales de la Caja de Ahorros San Fernando, la aparición de publicaciones como Revista Separata o, en el campo específico de la plástica, la irrupción abstracta en el trabajo de artistas como Gerardo Delgado, José Ramón Sierra, Juan Suárez, José Soto o Ignacio Tovar, entre otros ${ }^{5}$.

Si repasamos la nómina de autores que conformaron la exposición alcalareña, iniciados en la pintura en edades comprendidas entre los treinta y cuarenta años, observaremos que participan de características comunes desde un punto de vista estético: la adhesión a la figuración, el desarrollo de ciertos géneros temáticos, la formación académica en la Facultad de Bellas Artes de Santa Isabel de Hungría y su posterior labor como docentes en dicha institución. Todas ellas características esenciales para comprender su lenguaje. Como lo acredita el currículum de Francisco García Gómez (1936-2011), José Antonio García Ruiz (1935-2015), Francisco Borrás (1938), Justo García Girón (1941), Juan Cárceles (1952), Antonino Parrilla (1944) y José Corrales (1934).

Circunstancia común a todos ellos es el haber tenido como espacio expositivo preferente a la Galería Haurie, ámbito principal de la pintura realista en general, y de modo particular la sevillana, cuya actividad se mantiene con ejemplar coherencia en la actualidad, gracias al buen hacer profesional y a la sensibilidad de Magdalena Haurie, desde su apertura en $1976^{6}$.

Como se ha indicado, la sólida preparación por parte de estos artistas, y su ulterior dedicación a la enseñanza compaginada con el ejercicio de la pintura, hace que de manera destacada se adviertan sus cualidades y dominio técnico expresado en la excelencia del dibujo, la sabia composición y un uso cromático adaptado a sus argumentos. Medios que constituyen el catalizador eficaz para sus representaciones fantásticas, ya sean dedicadas a objetos inanimados a la manera de extraños bodegones que se apartan de su primitivo propósito sensual, personajes de morfología espectral o paisajes de naturaleza singular; predominando en todo una decidida voluntad de renunciar a la captación mimética de las cosas tal

5 Véase MARTÍN MARTÍN, Fernando: "Pintura contemporánea en Sevilla", en Sevilla y su provincia. Sevilla, 1993, pp. 363-415.

${ }^{6}$ Creada en 1975, la Galería Haurie abre sus puertas un año más tarde, siendo fundada por los pintores José Antonio García Ruiz, Antonino Parrilla y el matrimonio Luis Guerrero Bernabeu y Magdalena Haurie Vigné, la cual, y desde el fallecimiento de su marido, asume con eficacia la responsabilidad de la galería. 
como se presentan, a favor de una exploración personal en su anhelo de dotarlas de una nueva realidad subjetiva y creadora. De este modo nos inclinamos, a la hora de acotar su pertenencia estética, por la denominación de "Realismo Fantástico", conscientes de que toda definición es compleja y matizable.

\section{BODEGONES INTEMPORALES}

Primordialmente, el género del bodegón, desde su origen, ha tenido como tema esencial la representación culinaria con el fin de suscitar los sentidos de la buena mesa. De ahí su ubicación preferente en los salones de comer. No obstante, y como es de sobra conocido, existen distintas clases de bodegón respondiendo a su contenido, ya sean de flores, frutas, recipientes, o las clásicas naturalezas muertas, participando estas últimas de una intención trascendente, como Vanitas o alegorías de la futilidad de las cosas cuyo indicador más repetido es la alusión a la muerte a través de la representación de la calavera.

Una simple mirada por las obras reunidas en la aludida exposición del $\mathrm{Mu}-$ seo de Alcalá de Guadaíra nos advierte de la reiterada presencia de bodegones en casi todos los pintores; querencia que en cierto modo hay que relacionarla con su formación académica y su práctica docente, siendo el bodegón uno de los ejercicios habituales en el aula. Bodegones que en esta muestra se nos aparecen en una variada tipología en rica secuencia interpretativa, que transcurre desde el académico "bodegón ortodoxo" al bodegón cuyos componentes representativos conllevan implícito un significado simbólico, teniendo todos como hilo conductor el carácter fantástico que define al conjunto de la exposición. En el primer supuesto, el académico, entendido como composición de objetos sin un especial simbolismo, se encontraría Recuperación de las formas clásicas (Justo García Girón, 1975) (Figura 1), basado en original y heterodoxa coexistencia de objetos y seres en impecable factura dibujística.

Siguiendo este dictamen apreciamos, por ejemplo, en el magnífico bodegón titulado Reliquias de otoño (Francisco Borrás, 1975) (Figura 2) que, tras el conciso naturalismo y la delectación de los paños -factor común en el quehacer de los artistas seleccionados-, subyace un comentario melancólico expresado en las secas y rugosas hojas y en los ásperos cardos que aparecen en el contexto espacial difuso del fondo.

Con carácter de pesimismo metafísico, se encuentran los bodegones de José Corrales, maestro en el cuidado de texturas y precisión en el detalle, como testimonia su obra Trompe l'oeil (1974) (Figura 3). Trampantojo o suerte de complacencia en el equívoco, en prodigiosa escala de realidades fingidas: espiga de trigo, mariposa, lámpara minera ennegrecida y hoja de bloc sujeta por una chincheta a la pared. Por lo que respecta a Recuerdo de La Antilla (1975) y Hombre Naturaleza (1977), obras igualmente firmadas por Corrales, son imágenes metafóricas de desengaño sugeridas mediante la degradación y el paso del tiempo en las cosas. 
Un herrumbroso y deteriorado farol y un pez en descomposición en el primero, y en el segundo una aleatoria amalgama de objetos: fragmentos de escayola, cañas que sirven de inverosímil plataforma a unas semillas y a un bote oxidado como improvisado florero portador de una espléndida rosa; todo ello suspendido en un oscuro espacio sin referencias bajo una irreal iluminación ${ }^{7}$.

Como bodegones también se podrían calificar esas extrañas configuraciones a modo de grotescos personajes que bajo la denominación de "bufones" realiza Justo García Girón con los epítetos de La verdad (1975), La indulgencia (1975) y La mentira (1979), que son representaciones plásticas en su condición de variaciones sobre un tema. Que en realidad suponen tan solo un pretexto de estudio de paños de soberbios resultados, unido a un espléndido sentido cromático que nos trae a la mente el proverbial tratamiento de telas del maestro de Fuendecantos; especialmente el rotulado como Bufón de la verdad, aquí expresado en recreación de plegados que responden en sus caprichosas formas a estructuras interiores de elementos cóncavos de los que se vale para resaltar distintos aspectos volumétricos.

Asimismo arquetipos del buen hacer son las naturalezas silenciosas de Francisco García Gómez, como Bodegón del cesto y Bodegón de las caracolas (ambas de 1978), obras maestras en su género, donde el artista con gran oficio capta con supremo realismo objetos inanimados, presentados en el artesano recipiente ubicado a la manera clásica en una superficie horizontal a modo de alféizar o repisa; mostrando así la plasticidad morfológica de los elementos representados, sea la misma y precisa urdimbre del cesto, el matizado brillo de las conchas -en especial el nacarado del nautilus-, la luminosa y sensual blancura del paño, o la sólida y descarnada osamenta craneal de un bóvido.

\section{PERSONAJES INQUIETANTES}

Bajo la denominación de personajes inquietantes señalamos hacia un conjunto de obras cuya representación está protagonizada por seres de naturaleza fantástica e híbrida, imágenes turbadoras en su categoría de figuraciones extravagantes y grotescas. De esta manera se visualiza en El Físico (1995) o El dignatario (1996), telas de Francisco García Gómez, donde el sentido irónico se acompaña de lo burlesco en su intención satírica de acusación moral y crítica. Caso distinto es la obra titulada Aquelarre (1983) (Figura 4), del mismo autor; impactante y sobrecogedora representación de excelente factura plástica, dedicada al principal protagonista ritual de brujería en su oficio satánico de tinieblas y encarnación de macho cabrío. Desde la oscuridad del fondo compositivo destaca la recortada e

7 Véase CÁRCELES PASCUAL, Juan Francisco: El pintor José Corrales y el Realismo Mágico. Sevilla, 2012. 
imponente figura, cuya volumetría es determinada por el amplio registro de paños en sus variadas formas y pliegues; así como por los matices cromáticos, y por una fluidez de pincelada conseguida por el artista a través de estudios previos. Cualidad igualmente observable en otras realizaciones, como en su logrado $\mathrm{Al}$ quimista (1983) (Figura 5).

Dentro de la misma línea de imágenes desasosegantes, diríase surgidas de un mal sueño o pesadilla, se encuentran obras como El samurai (1977), de José Antonio García Ruiz, u Hombre anónimo (1982), de Juan Francisco Cárceles. Seres espectrales habitantes de un submundo, transeúntes solitarios y erráticos cuya entidad física parece encontrarse en proceso de mutación fósil o pétrea. Envueltos en una atmósfera crepuscular de silencio; impresión que se acentúa por el uso de ocres terrosos que otorgan a la composición una tonalidad homogénea. En El regreso (1979), Cárceles ofrece un escenario más onírico, de concomitancias surreales, donde los aleatorios personajes de similar fisonomía pétrea -sobre todo el ubicado a la izquierda de la composición-sufre una desintegración de sus partes, que se esparcen en un espacio ambiguo compartido por enigmáticos rostros o individuos incómodamente enjaulados a la manera de aves. Tanto por el cromatismo de tonalidades amarillentas, como por esas partes que se descomponen de la figura, nos vienen a la mente ciertas iconografías del gran dibujante y grabador José Hernández y su universo de putrefacción y decadencia.

\section{COMPOSICIONES CON DESNUDO}

Como bien recordaba Kenneth Clark en su clásico ensayo sobre el desnudo, este "no es un tema del arte, sino una forma de arte". Un modo de interpretar el cuerpo con distinto propósito y significado. El desnudo natural, femenino o masculino, es parte fundamental de la formación en las facultades de Bellas Artes. Dibujo del natural cuya prioridad es saber captar la expresividad del cuerpo humano ya sea en movimiento o en reposo. Francisco Borrás hace acopio sabio de conocimiento en su proverbial gran oficio, aquí vertido en varias composiciones que tomando el desnudo femenino como excusa, sitúa a las protagonistas en contextos imprecisos bajo lo que podríamos calificar de ensoñaciones. Así ocurre en El sueño del ángel (1990), Nenúfares (1987) y Homenaje a Bécquer (2012), entre otros. A veces de carácter alegórico, como el realizado en admiración al autor de Rimas y Leyendas. Desnudos idealizados en diferentes poses y acciones en lugares fantásticos con luminosas tonalidades y especial acento en la pincelada. Hermosas veladuras que suavizan las gradaciones dando brillo a anatomías y ropajes.

En distinto registro plástico, aunque enfatizando una realidad ambiental merced a una ambigua simultaneidad de conceptos -interior, exterior- y presidido por el desnudo como eje central de la composición, se encuentran las obras Espacio para una pleamar ausente (1986) y La casa de los sueños (2007), de Juan Francisco Cárceles (Figura 6), que recrean con acierto y excelente dibujo el cuerpo femenino 
tendido en sus dos poses clásicas, de frente y de espaldas; cuerpos anónimos en reposo, superpuestos a un paisaje soñado donde los rosas del cuerpo se fusionan con los grises del entorno. La composición claramente lineal es rota por la sinuosidad de los desnudos cuerpos femeninos, recreando la sensualidad y belleza anatómica de las protagonistas.

\section{RETRATOS CON SIGNIFICADO}

Sin duda, si hay un género que acompaña a la Historia del Arte desde sus inicios, este es el retrato. Ya sea individual o en grupo. El retrato como voluntad de fijar la realidad fisonómica del modelo, sus rasgos faciales como individuo. Retrato idealizado que responde más a un deseo que a la auténtica identidad del sujeto. $\mathrm{O}$ el autorretrato, el cual es casi siempre una confesión interesada en el sentido de mostrarse con la idea de transmitir al receptor una imagen construida de sí mismo.

Los retratos a comentar pertenecen a otra clasificación. Responden a lo que podríamos denominar como retratos en pose de figurantes, de actores; dentro de un contexto singular y participando de una extraña escenografía. Tal como ejemplifica A solas en silencio, de Juan Francisco Cárceles (1980), retrato infantil ubicado en enigmática atmósfera nubosa, a la manera de imprevisible aparición onírica, teniendo como una única referencia tangible una suerte de espejo que parece justificar una incierta abertura o frontera de un mundo a otro. Con gran verismo formal Cárceles muestra su capacidad para el dibujo, sus dotes para captar la expresión de la mirada de una niña dirigida un tanto sorprendida al espectador, diríase ataviada con atuendo decimonónico ejecutado con precisa minuciosidad en los pliegues del vestido. Figura y fondo aparecen bañados por sutiles tonos de tierra clara que se expanden por toda la superficie de la composición. Características que le emparentan con la obra de Eduardo Naranjo, por ejemplo.

El jardín del diablo (2008) (Figura 7) y El jardín de Rocío (2009), obras de José Antonio García Ruiz, son asimismo retratos femeninos aunque ignoramos su identidad. Retratos en un contexto mítico, de leyenda, que recuerdan al universo maravilloso y estético de los prerrafaelistas, y de manera concreta a Eduard Burne-Jones y sus prolijas interpretaciones de las sagas medievales dedicadas al rey Arturo. Solo que en el caso de El jardín del Diablo García Ruiz traslada al personaje, a juzgar por los elementos arquitectónicos, a un entorno próximo al Renacimiento. Marco fabuloso, exótico, de promiscuas y extraña coexistencia entre frondosas plantas, animales y bodegones de singulares frutos; todo ello expresado en planos sucesivos dentro de una composición distribuida a la manera de un retablo, que sirve para ordenar la mirada del espectador. Veladuras y transparencias concatenadas configuran y crean esa atmósfera propia del relato surreal, con pasión detallista. Características y lenguaje que vuelven a repetirse en El jardín de Rocío, donde la naturaleza cobra mayor protagonismo, actuando a 
la manera de aura en torno a la elegante figura femenina de rica y decorativa vestimenta; dirigiendo la figura su mirada a alguien o algo que no percibe quien la contempla.

Sorprendente es el retrato de Francisco García Gómez, El alquimista (1983) (Figura 5), que el autor realiza a su pariente Manuel Márquez Ortiz. Representado como tal alquimista, con atuendo a la manera de los retratos de media figura renacentistas pero atendiendo al carácter de su mágica profesión. De ahí los elementos y objetos que le acompañan. Matraces, moles, extraños envases, cráneos, como en el que parece apoyarse su esquelética y sarmentosa mano. Con expresión seria, abundante cabellera, García Gómez parece haber querido representar al personaje acorde con su más peculiar distintivo profesional, esto es, su poder transformador, de mutación, empezando por su propio cuerpo. Pues una de sus partes, la izquierda, está configurada por una ecléctica y heterogénea agrupación de objetos, recipientes, engranajes, tuercas... y una vez más, cráneos. Cráneos velados que se nos descubren tras un luminoso tejido transparente, un resplandor expandido y que actúa de fuerte contraste con el resto de la figura pareciendo subrayar con ello el mismo instante de metamorfosis que sufre el personaje.

\section{PAISAJES DE LA IRREALIDAD}

Bajo este epígrafe se dan cita distintos modos de concebir el paisaje, que siguiendo el mismo paradigma fantástico recrean con gran coherencia lingüística y estética sus artífices; una realidad particularmente imaginativa. Soplo de primavera, de José Antonio García Ruiz (1988), muestra un paisaje lacustre cuyas temblorosas superficies pobladas de nenúfares - planta asociada al más allá- se pierde en la lejanía del horizonte. Sobre él, en el celaje, una niña a la manera de Céfiro insufla aire haciendo que del cesto portador se derramen flores. Visión poética y lírica, armoniosamente plasmada por diversas gamas cálidas de tonos amarillos, sienas y verdes, en conseguida conjunción de transparencias y veladuras que contribuyen a la creación de una atmósfera idílica.

Por otro lado Antonino Parrilla, desde su notable creatividad polifacética, en uso de técnicas diferentes, ofrece dos interpretaciones paisajísticas. Desde una evidente referencia admirativa al pintor holandés, toma como motivo sus emblemáticos girasoles, como en Homenaje a Van Gogh (1988), representados aquí no como las célebres variaciones de bodegón, sino a la manera de extenso mar floral en nítida y significativa división compositiva. Una zona inferior telúrica, configurada por un submundo mágico ocupado por pequeños animales e insectos que comparten espacio junto a una diáspora de diminutas burbujas multicolores que se expanden a la manera de semillas fertilizantes como queriendo otorgar vitalidad y energía a la naturaleza. La zona superior de la composición, en amplia panorámica, es ocupada íntegramente por los girasoles. Esta división compositiva actúa como equilibrio y a la vez afortunado contraste entre el vivo y brillante 
colorido amarillo de los girasoles, y el predominio de los ocres. Con el nombre de Cosmos (2007), Parrilla realiza una composición cerámica distribuida en perfecta simetría cuadrada. Cada uno de los paneles presenta cuatro microhistorias pobladas por personajes de difícil naturaleza y definición, que parecen estar en actitudes de agitación ante la omnipresencia de una amenazante esfera. Aunque cada una de las historias puede tener valor como relato, su visión crea una secuencia argumental. Es interesante comprobar, por una parte, y a través del distinto tratamiento de las formas junto a las gradaciones cromáticas, la dialéctica oscilante entre figuración y abstracción. Como así mismo, y de no menos interés, es el paralelismo y coherencia del artista con respecto a la temática o iconografía de uno de los paneles -concretamente el situado en el ángulo inferior derecho- con el relieve de la obra titulada La Misión (1982), presente también en la muestra, donde a la manera de evocación fantástica se multiplican y esparcen en confuso abigarramiento un conjunto de rostros de filiación clasicista, como esa visión onírica del personaje que, arrodillado, aparece frente al portal de un templo.

Como "paisajes de la memoria" nos atrevemos a calificar la obra de Justo García Girón titulada La casa de las columnas (1980), tela que pertenece a un ciclo, o conjunto de pinturas, que tienen como temática principal fachadas de edificios, ventanas, portones, etc., que devienen del recuerdo de una Sevilla vivida y sentida por el artista. Una ciudad, Sevilla, que conoce como pocos y a la cual apela en clave metafórica a través de referencias. A veces fragmentos urbanos identificables, presentes por el valor significativo que para el artista tienen. No se trata de una simple catalogación de reconocimientos que plausiblemente puedan ser identificados. Girón parece querer añadir un plus, una representación en clave de dos realidades subjetivamente interpretadas. Una de carácter urbano, otra campestre; sintetizadas en imágenes superpuestas como acto rememorativo que, ante la inexactitud subjetiva, gusta de intercalar no sin cierta ironía notas fantásticas con la presencia inverosímil de pseudo organismos tentaculares que se desarrollan como bucles en el espacio. Como si quisiera añadir un toque misterioso a lo cotidiano y visible. El conseguido equilibrio de la composición se ve, una vez más, completado por la sabia gama tonal empleada que, a manera de catalizador, se distribuye por diferentes zonas del lienzo creando confrontaciones entre luminosidad y penumbra. Lo cual confiere al paisaje una seductora realidad imaginada.

El recorrido que ofrece el discurso de esta selección de obras lleva al espectador a transitar por unas visiones distorsionadas de la realidad en las que cada autor ofrece una perspectiva muy personal. Es por ello por lo que no puede considerarse a estos artistas como una escuela o movimiento artístico, sino como a un grupo de creadores, los cuales se han nutrido de distintas experiencias que han sido llevadas a sus trabajos siempre bajo un nexo de conexión muy concreto: el dibujo. Magníficos dibujantes y con una más que evidente vertiente académica, sustentan estas aportaciones de carácter fantástico en un eficaz dibujo cargado de 
maestría, producto de la formación en la Facultad de Bellas Artes de Santa Isabel de Hungría, institución de la cual muchos de ellos han formado parte como docentes.

El componente fantástico resulta a priori el más llamativo, aunque la contemplación diseccionada de las obras lleva a nuevas cotas de trascendencia en las que el dibujo siempre juega el papel protagonista. La reflexión plantea la pregunta: ¿funcionaría el matiz onírico de no ser por la maestría del dibujo?

Resulta importante el destacar la vinculación con la figuración académica, la cual está especialmente condicionada por la tradición de la pintura barroca sevillana. Este carácter está presente en los numerosos bodegones, los cuales conectan la visión de atemporalidad con el costumbrismo murillesco y su gusto por el detalle. Las degradaciones de la carne que presenta Juan Cárceles o las grotescas distorsiones de los personajes de la obra de García Gomez no son sino una extensión de las sórdidas visiones de las vanitas de Valdés Leal. Añadir a estos detalles el protagonismo que adquieren los minuciosos trabajos de telas y paños que conectan directamente con la obra de Zurbarán, siendo destacable citar los bufones de Girón, el Aquelarre de García Gómez o las obras de Borrás, en las que los ropajes complementan a unos rotundos desnudos académicos de factura clásica y poderosa sensualidad.

Las influencias estilísticas de estas obras no solo se reducen a la tradición local sevillana, sino que en algunos casos se extienden a otras tendencias europeas, tales como el simbolismo de Cárceles, el vivo colorido prerrafaelita de las obras de García Ruiz o los coqueteos surrealistas de Antonino. El grueso de la producción de estos artistas se desarrolla a mediados de la década de 1970, anticipándose en cierto modo al neomanierismo o nuova maniera italiana de los años ochenta, en donde representaciones clasicistas de figuras humanas se sumergían en amaneradas escenas anacrónicas con cierto gusto por lo mitológico y lo decorativo. Por lo tanto, es importante destacar que se trata de una pintura culta en la que las influencias y el trasfondo académico consiguen dotarlas de un atractivo inquietante y de una rotunda personalidad.

De ahí que este conjunto de obras deba ser entendido como producto de unos artistas que poseen en común una formación que cada uno ha ido complementando con sus propias influencias estéticas y percepciones de la realidad. Caer en la fácil catalogación o agrupación dentro de una misma escuela o movimiento estético sería algo erróneo y en cierto modo, perezoso, ya que cada uno de estos artistas requiere de una reflexión individualizada que permita acceder al entendimiento de aquello que querían transmitir con su obra.

Fecha de recepción: 25 de octubre de 2017

Fecha de aceptación: 31 de enero de 2018 


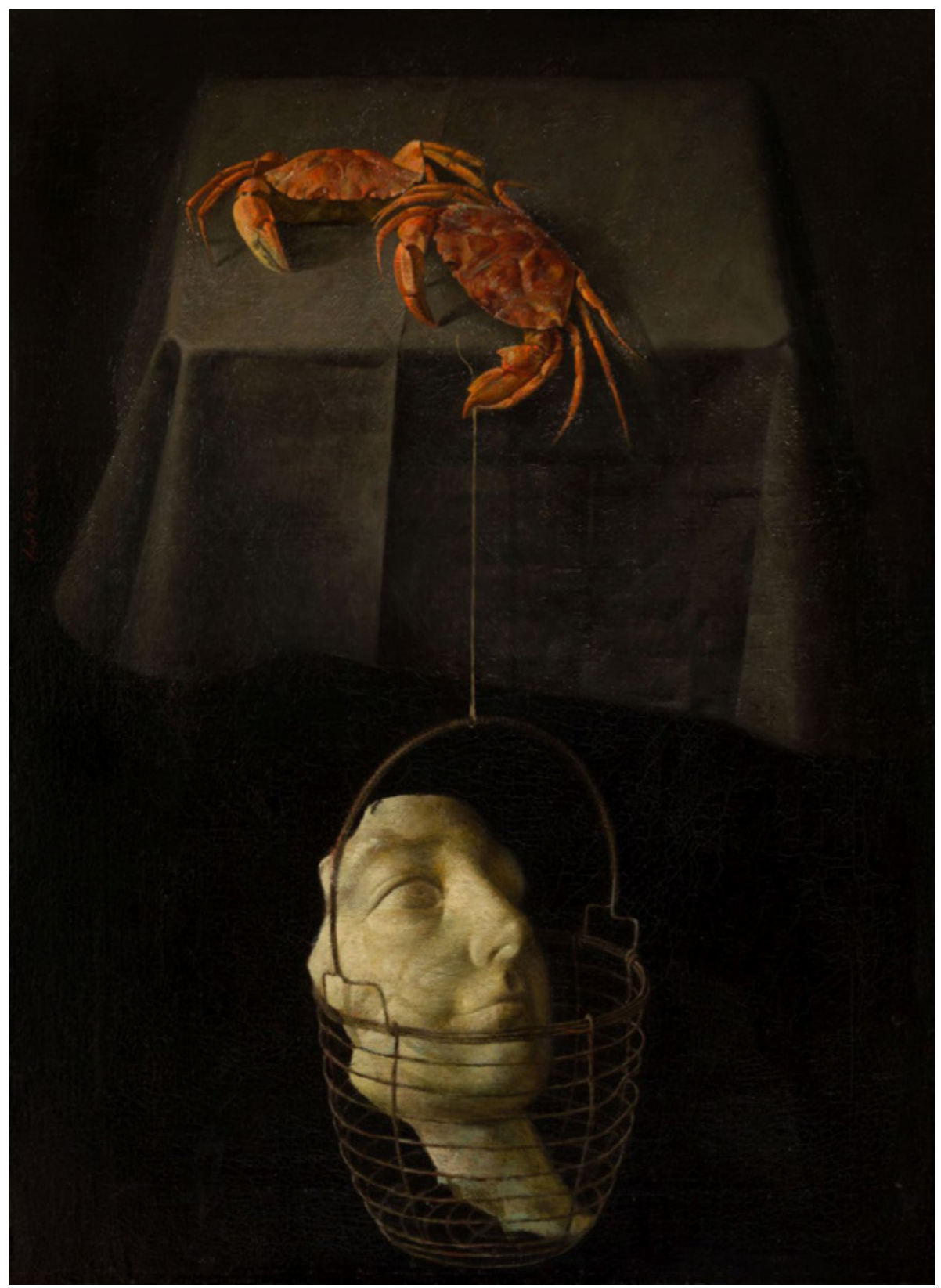

Figura 1. Justo Girón, La recuperación de las formas clásicas, 1975.

LABORATORIO DE ARTE 30 (2018), pp. 457-474, ISSN 1130-5762 e-ISSN 2253-8305 - DOI http://dx.doi.org/10.12795/LA.2018.i30.25 


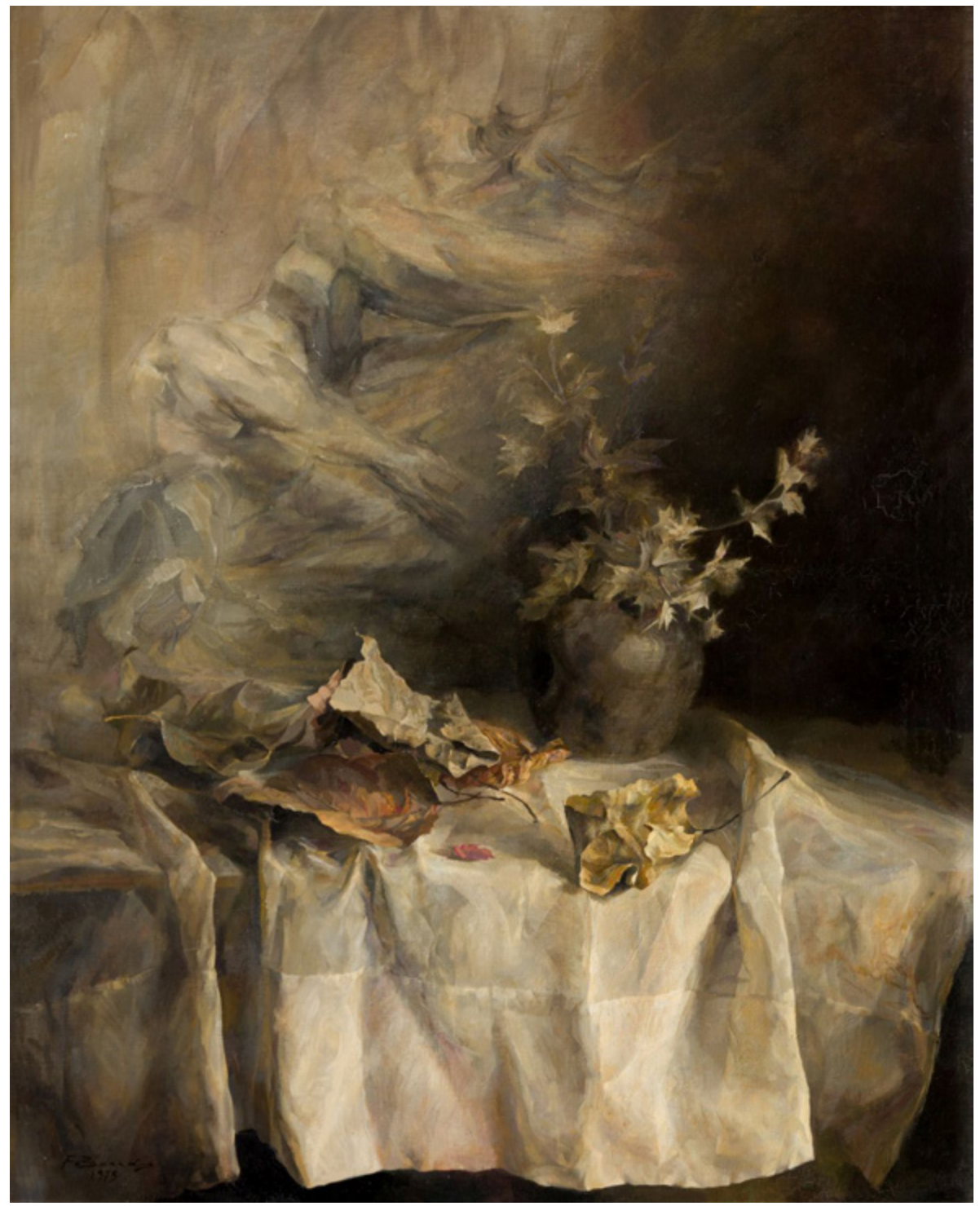

Figura 2. Francisco Borrás, Reliquias de otoño, 1975. 


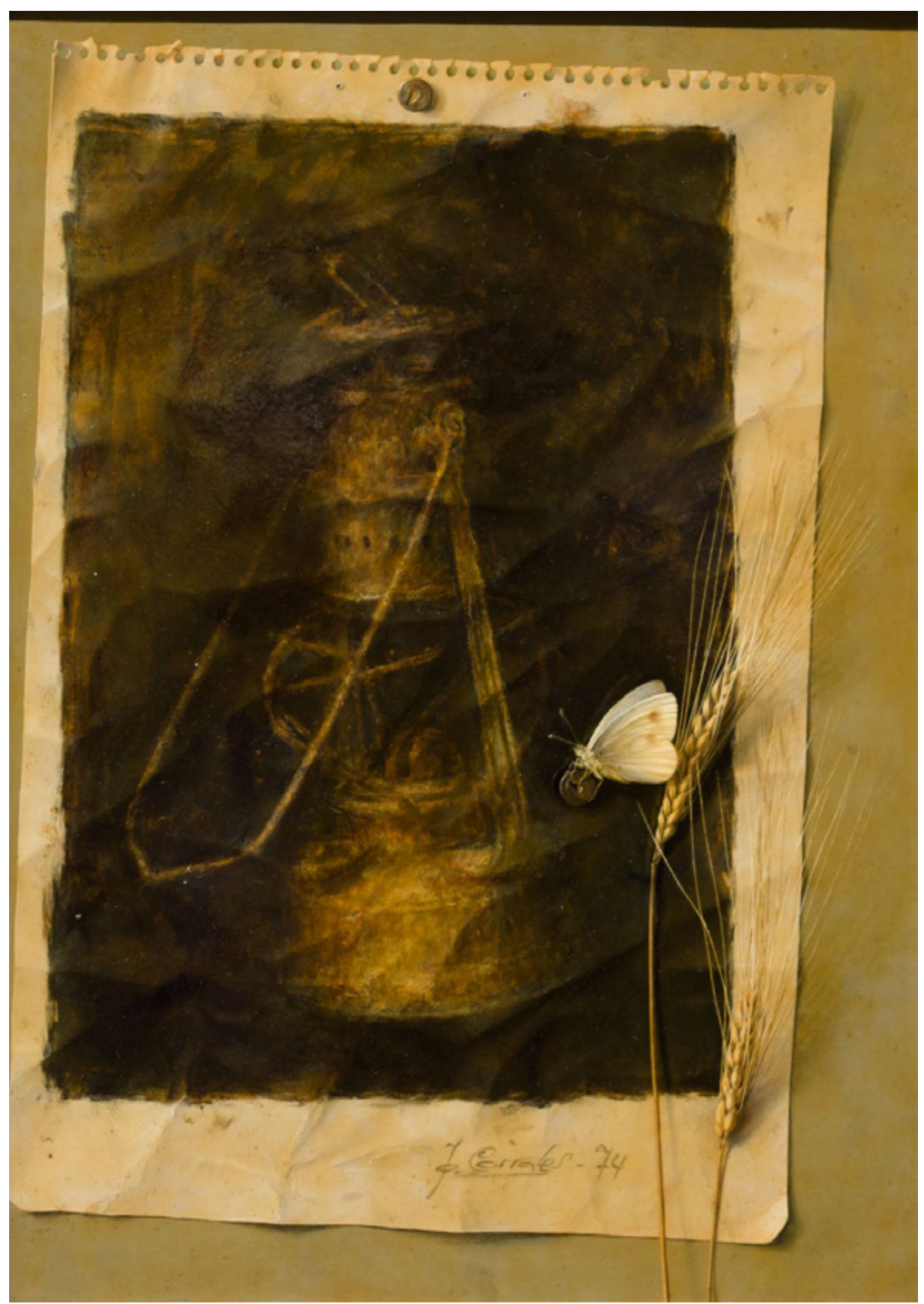

Figura 3. José Corrales, Trompe l'oeil, 1974.

LABORATORIO DE ARTE 30 (2018), pp. 457-474, ISSN 1130-5762 e-ISSN 2253-8305 - DOI http://dx.doi.org/10.12795/LA.2018.i30.25 


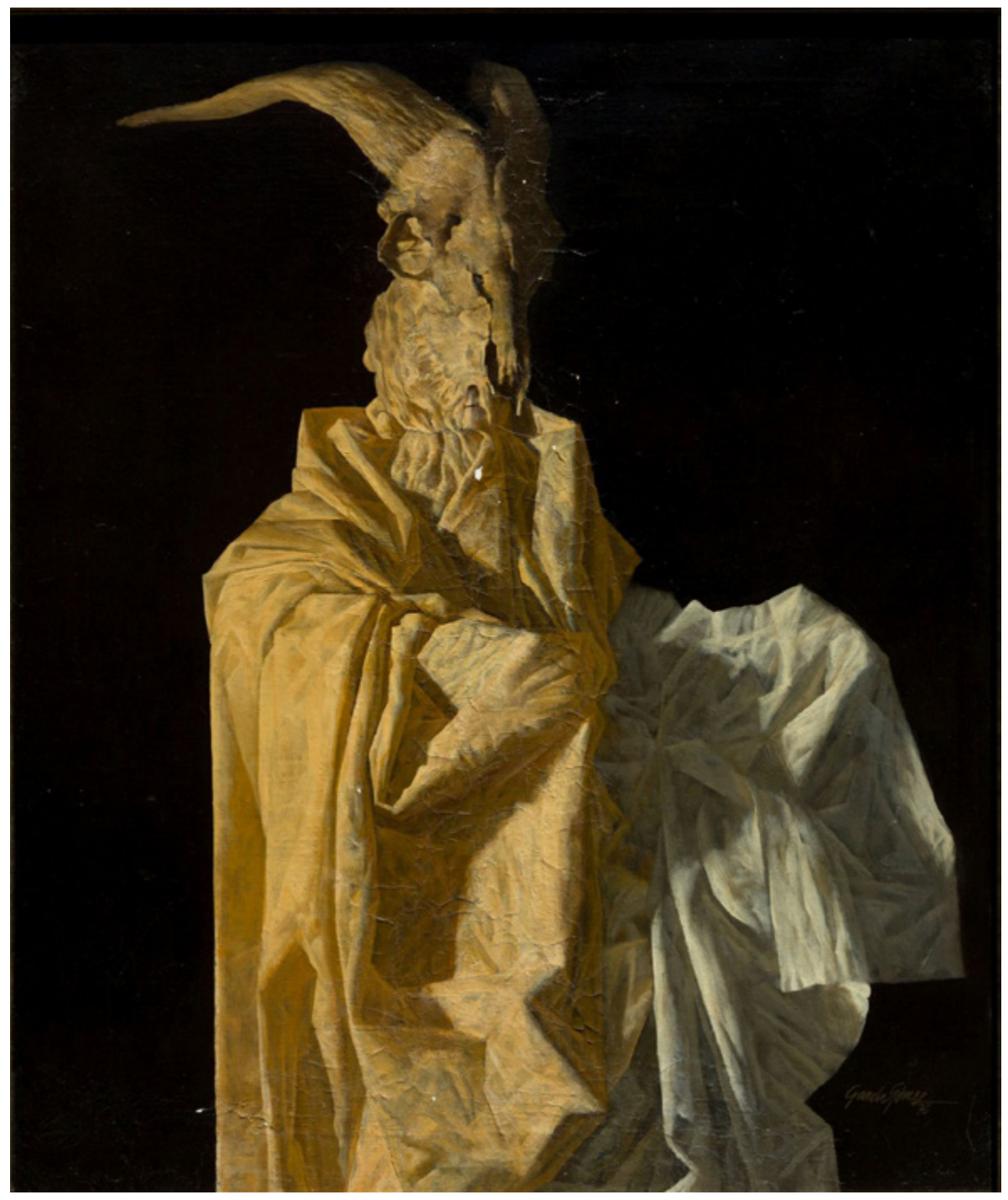

Figura 4. Francisco García Gómez, Aquelarre, 1976.

LABORATORIO DE ARTE 30 (2018), pp. 457-474, ISSN 1130-5762

e-ISSN 2253-8305 - DOI http://dx.doi.org/10.12795/LA.2018.i30.25 


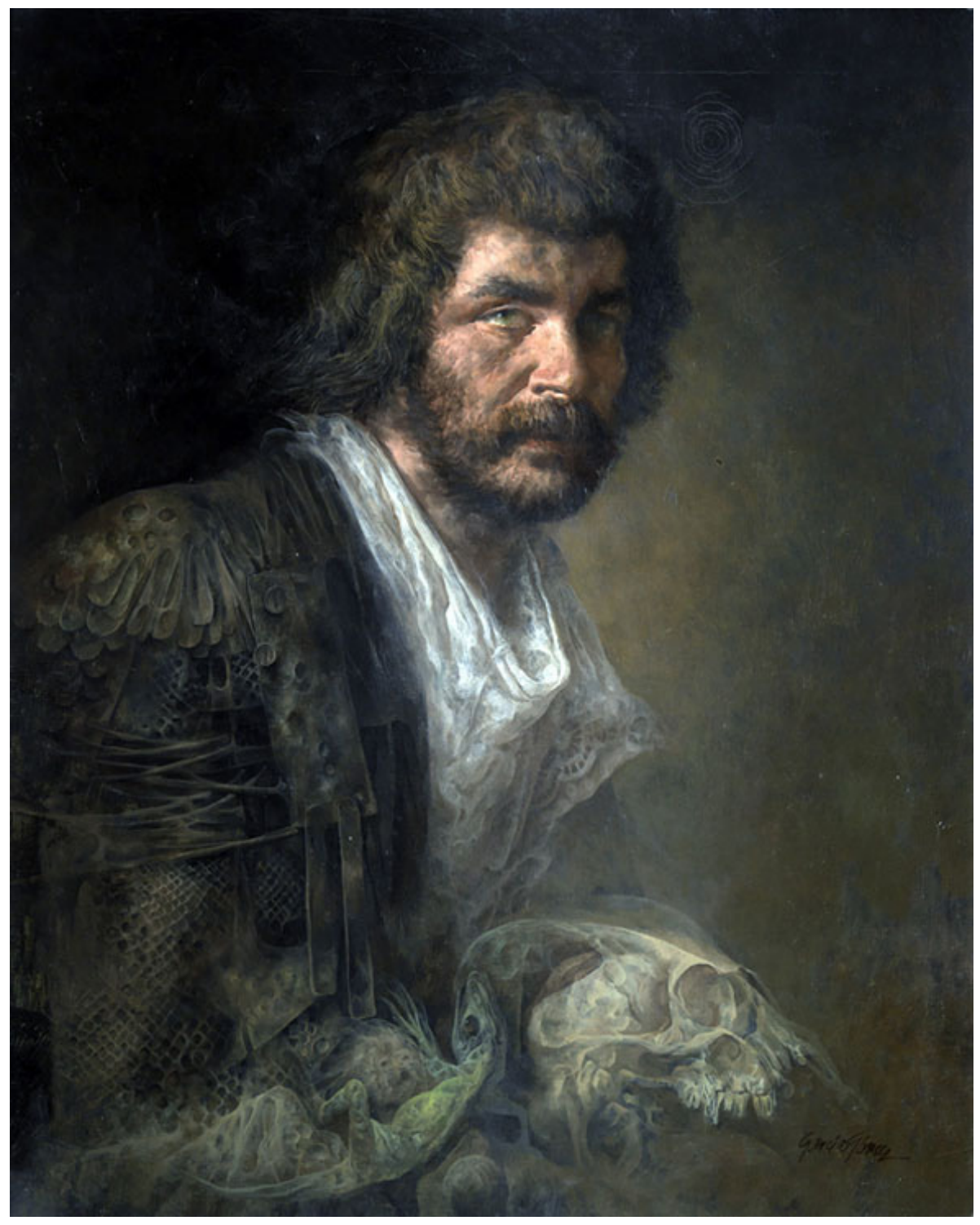

Figura 5. Francisco García Gómez, El alquimista, 1983.

LABORATORIO DE ARTE 30 (2018), pp. 457-474, ISSN 1130-5762 e-ISSN 2253-8305 - DOI http://dx.doi.org/10.12795/LA.2018.i30.25 


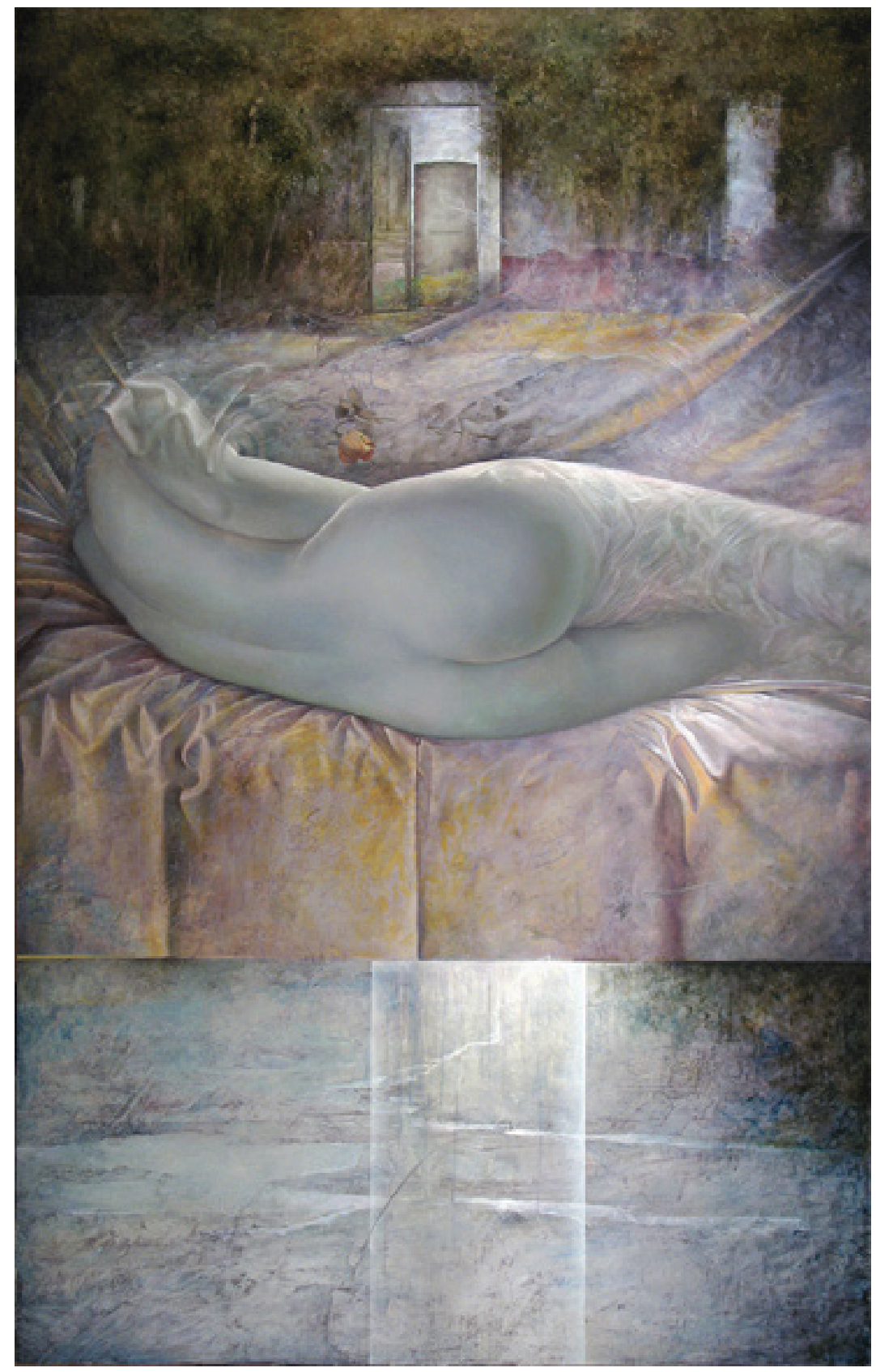

Figura 6. Juan Francisco Cárceles, La casa de los sueños, 2007.

LABORATORIO DE ARTE 30 (2018), pp. 457-474, ISSN 1130-5762

e-ISSN 2253-8305 - DOI http://dx.doi.org/10.12795/LA.2018.i30.25 


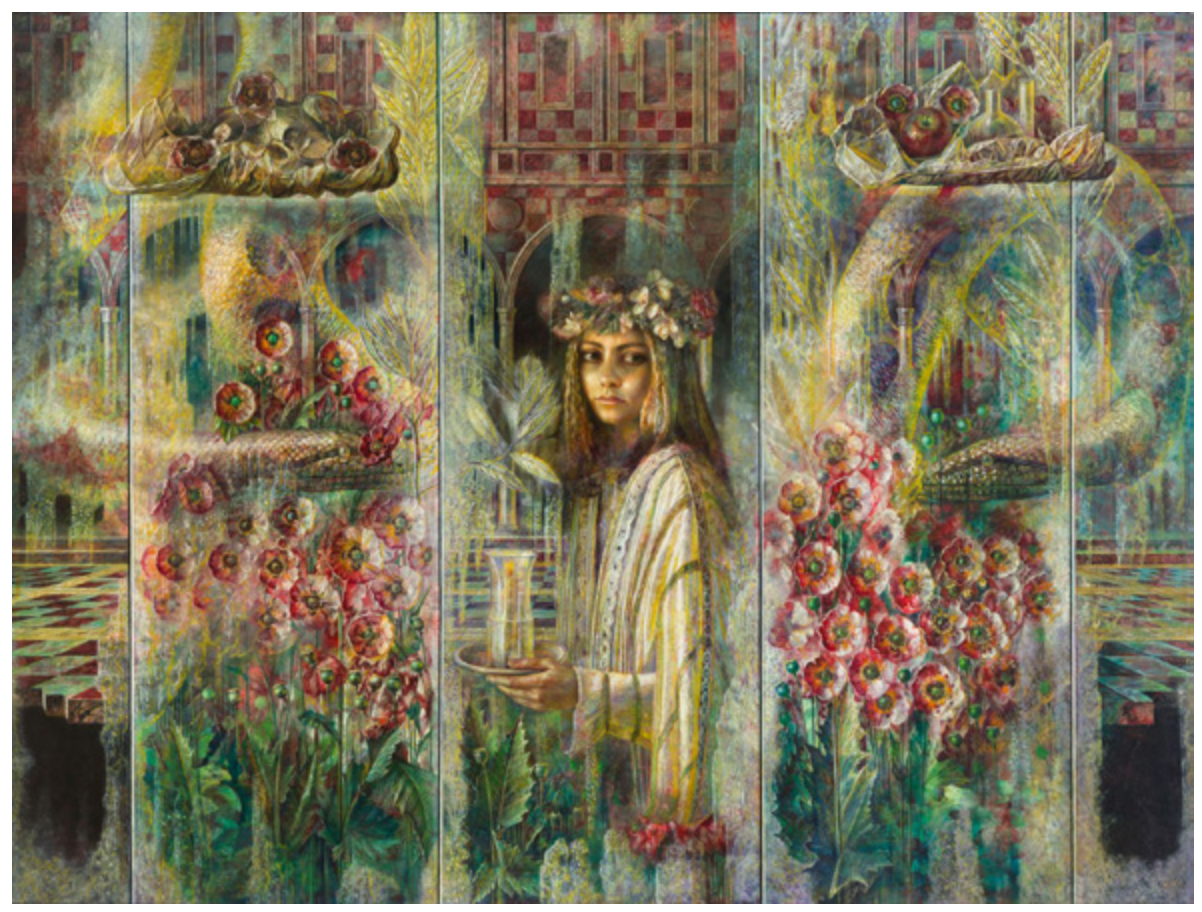

Figura 7. José Antonio García Ruiz, El jardín del diablo, 2008. 


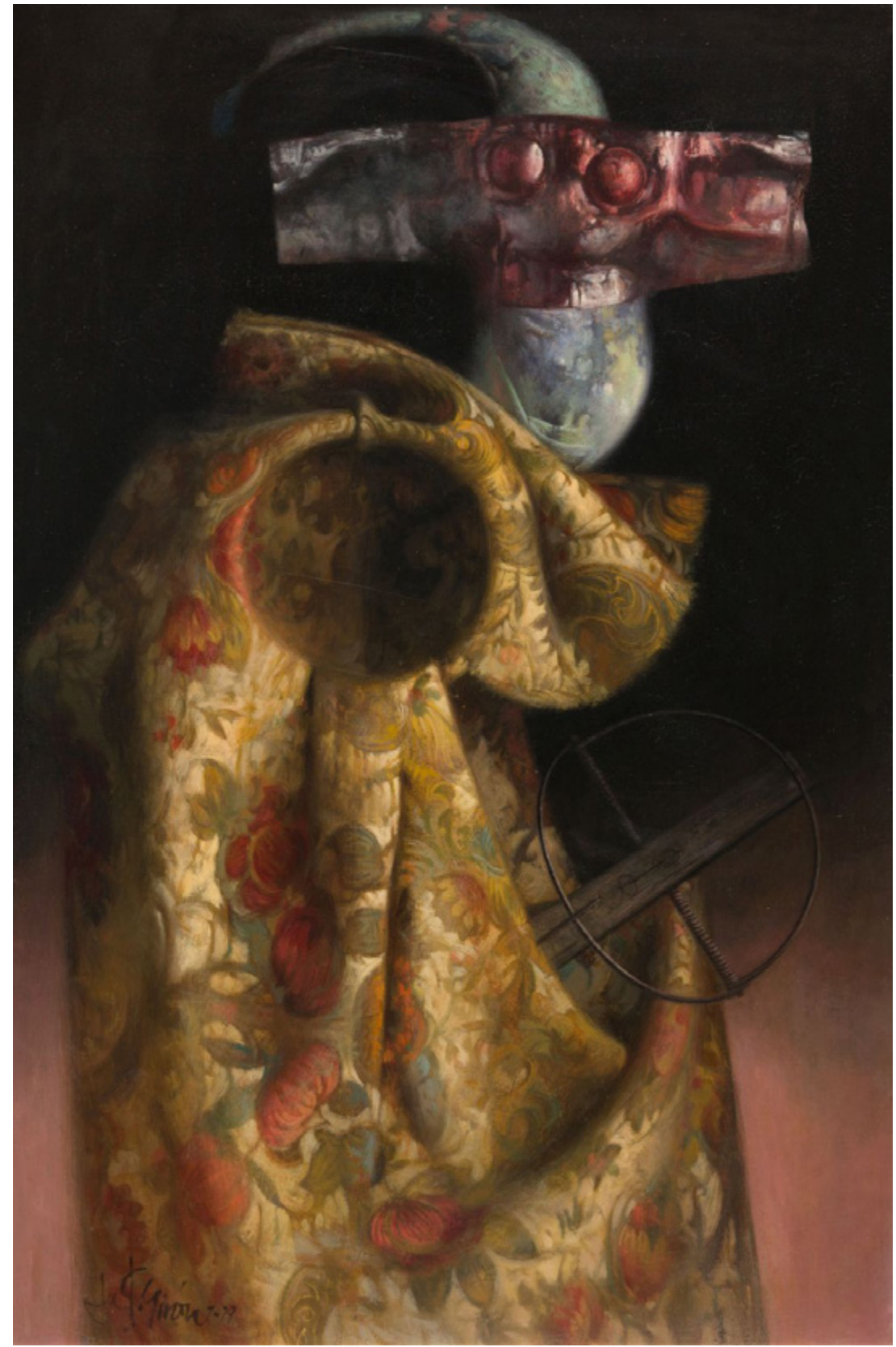

Figura 8. Justo Girón, La bufanda de la mentira, 1979. 